Original Research Paper

\title{
Assessment of the Cenozoic Erosion Amount using Monte Carlo Type-Petroleum Systems Modeling of the Hammerfest Basin, Western Barents Sea
}

\author{
${ }^{1}$ Krzysztof Jan Zieba, ${ }^{2}$ Matthias Daszinnies, ${ }^{3}$ Benjamin Emmel, \\ ${ }^{3}$ Ane Lothe, ${ }^{3}$ Arnt Grøver and ${ }^{1}$ Stephen Lippard \\ ${ }^{1}$ Department of Geology and Mineral Resources Engineering, \\ Norwegian University of Science and Technology (NTNU), NO-7491 Trondheim, Norway \\ ${ }^{2}$ Migris AS; PO Box 1208 Pirsenteret, NO-7462 Trondheim, Norway \\ ${ }^{3}$ SINTEF Petroleum; Basin Modelling, S. P. Andersens veg 15 B, NO-7031 Trondheim, Norway
}

Article history

Received: 01-12-2014

Revised: 20-01-2015

Accepted: 15-02-2015

Corresponding Author:

Krzysztof Jan Zieba

Department of Geology and

Mineral Resources

Engineering, Norwegian

University of Science and

Technology (NTNU), NO-7491

Trondheim, Norway

Email: krzysztof.j.zieba@ntnu.no

\begin{abstract}
The Cenozoic uplift and erosion is often believed to be a major risk factor in hydrocarbon exploration in the Barents Sea causing petroleum redistribution and leakage from filled traps. Therefore, the estimation of erosion amount is an important but often underrepresented task in the basin modeling procedure. The assessment of erosion magnitudes and spatial distribution by geochemical and thermo chronological methods results in very different estimates and/or does not consider uncertainties of input data. In this study, this problem is approached by using Monte Carlo simulation techniques in secondary migration basin modeling. Thereby, amounts of early and late Cenozoic erosion episodes are described by probability distributions and the modeling results were evaluated considering their uncertainty ranges. In addition, overpressure and related leakage scenarios are considered in the petroleum basin models to study their effect on modeling results. It is shown that the early Cenozoic erosion event had a generally higher erosion magnitude than the late Cenozoic event (1.0-1.3 and $0.4-1.2 \mathrm{~km}$ respectively). Modeled erosion estimates are not very sensitive to overpressure modeling which is found to affect only the early Cenozoic erosion amount estimates at low degree.
\end{abstract}

Keywords: Barents Sea, Hammerfest Basin, Erosion, Basin Modeling, Monte Carlo

\section{Introduction}

From a hydrocarbon exploration perspective, the southern Norwegian Barents Sea (Fig. 1a) is an immature area in the Arctic region and until now the findings of major gas and oil discoveries are below expectations. One of the reasons for this might be related to the complex Cenozoic thermo-tectonic history of the region (e.g., Dimakis et al., 1998; Faleide et al., 2008). The Cenozoic Barents Sea (Fig. 1, 2) was affected by several episodes of vertical tectonic movements during the Cenozoic, which influenced the present day seafloor topography (Riis and Fjeldskaar, 1992; Green and Duddy, 2010; Knies et al., 2014). Moreover, these episodes were associated with sediment mass re-distribution caused by local erosion and re-deposition influencing the rock and fluid properties of the underlying sedimentary units. For example, dry traps with residual oil shows and paleo-oil water contacts are interpreted to indicate trap drainage during Cenozoic erosion episodes by processes such as cap-rock leakage, reservoir tilting and fault reactivation and associated pressure and temperature changes (Ohm et al., 2008). If correct, a better understanding of the dynamic response of the petroleum system to the basin evolution will reduce the risks in hydrocarbon exploration in the region. Accordingly, detailed erosion estimates are crucial in reconstructing the burial histories of the Barents Sea basins. Several approaches have been published to quantify the magnitude, lateral and temporal distribution of erosion via paleotemperature indications such as Apatite Fission Track Analysis (AFTA), Vitrinite Reflectance (VR), geochemical and geophysical methods or by deterministic basin modeling (Riis and Fjeldskaar, 1992; Richardsen et al., 1993; e.g., Cavanagh et al., 2006; Ohm et al., 2008; Green and Duddy, 2010; Duran et al., 2013). 


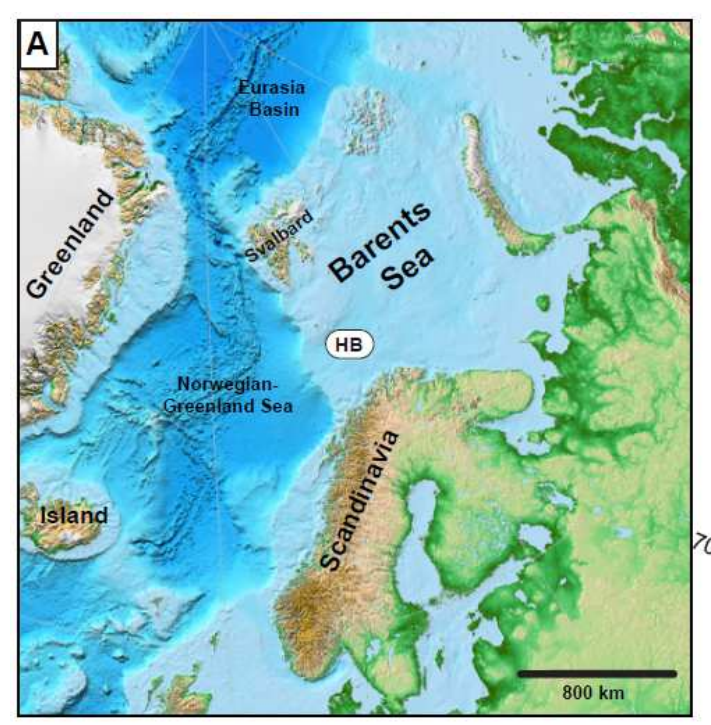

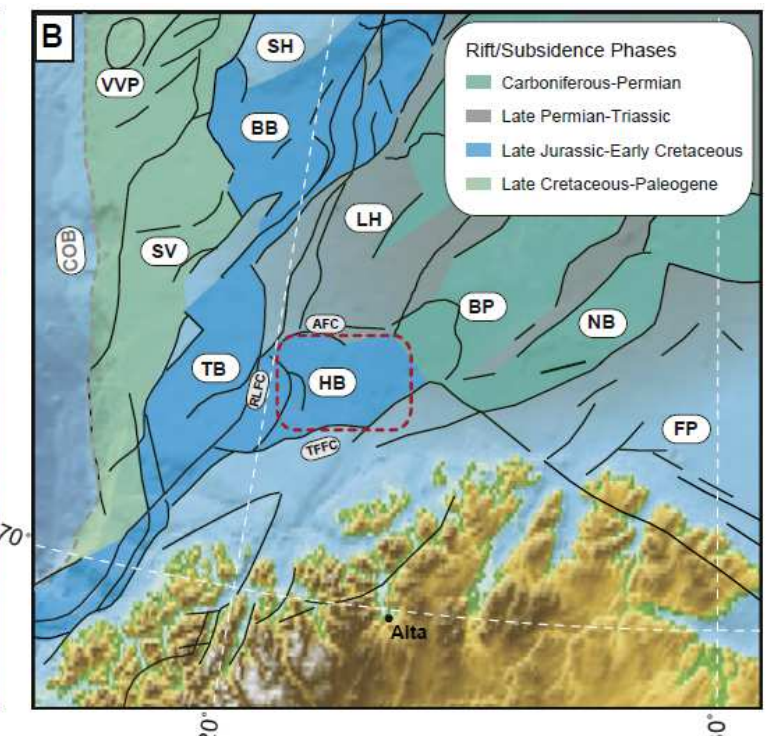

¿े

Fig. 1. (A) Location of the working area in the Arctic region based on ETOPO 5 data-set. (B) Main structural elements in the SW Barents Sea. The Hammerfest Basin (highlighted by the red box) is a fault-bounded $150 \mathrm{~km}$ long and $70 \mathrm{~km}$ wide basin within the SW Barents Sea tectonic realm (modified from Clark et al., 2013) and based on Faleide et al. (2008); Jakobsson et al. (2008). Abbreviations: AFC: Asterias Fault Complex, BB: Bjørnøya Basin, COB: Continent-Ocean Boundary, FP: Finnmark Platform, HB: Hammerfest Basin, LH: Loppa High, NB: Nordkapp Basin, BP: Bjarmeland Platform, RLFC: RingvassøyLoppa Fault Complex, SH: Stappen High, SV: Sørvestsnaget Basin, TB: Tromsø Basin, TFFC: Troms Finnmark Fault Complex, VVP: Vestbakken Volcanic Province

However, for the south-western Barents Sea they often lead to very different magnitude estimates ranging from about $0.5 \mathrm{~km}$ to more than $2 \mathrm{~km}$.

In this study we focus on the effect of the Cenozoic thermo-tectonic history of part of the Hammerfest Basin (HB), the best investigated basin in the Norwegian Barents Sea. We use a probabilistic secondary migration basin modeling approach (Sylta and Krokstad, 2003; Sylta, 2004) to test different erosion scenarios established using AFT and VR data (Duddy, 1998; Green and Duddy, 2010). The basin modeling results are calibrated against observed oil and gas column heights reported from different exploration wells within the HB.

\section{Geological Overview}

The sedimentary basins within the Barents Sea comprise late Devonian to recent successions (Dalland et al., 1988). In the western Barents Sea, sedimentation patterns are closely linked to extensional tectonic episodes which affected the region since the late Paleozoic. Earliest rift basin formation is documented along structural basement anisotropies (Gabrielsen et al., 1990; Gernigon et al., 2014), where faulting caused the development of a Devonian graben system in the southern Barents Sea (Faleide et al., 2008; Henriksen et al., 2011b). During the Late Carboniferous until the Early Permian the entire Barents Sea evolved as a carbonate platform (Worsley,
2008; Henriksen et al., 2011b). Subsequently, the sedimentary environment changed to mainly a siliciclastic dominated realm (Fig. 3) and the Late Permian-Triassic basins were filled with eroded material from the hinterland (Glørstad-Clark et al., 2010). During the Triassic-Jurassic times several transgressive and regressive cycles prevailed as documented by Glørstad-Clark et al. (2010). Widespread deltaic to alluvial systems existed in the Early Jurassic and were submerged by a Middle Jurassic regional transgression (Worsley, 2008). The structural architecture of the present day basin and high configuration was largely determined by the tectonic activity at the end of the Jurassic to Early Cretaceous (Fig. 1b). In particular, the tectonic setting of the Late Jurassic leads to deposition of the major hydrocarbon source rock in the Norwegian Barents Sea i.e., the Hekkingen Formation (Fig. 3).

In the Early Cretaceous, basins along the western margin experienced their main subsidence phase. In this phase depocentres developed in the Tromsø and Bjørnøya basins and an increased subsidence in the HB occurred (Faleide et al., 1993; Worsley, 2008). During the Late Cretaceous, rifting and subsidence continued west of the HB, while the areas to the east (including the HB) were subjected to uplift and erosion which continued into the Paleocene (Faleide et al., 1993; Worsley, 2008). During the Late Paleocene, the entire western Barents Sea was dominated by subsidence due to a major transgression episode (Vorren et al., 1991). 


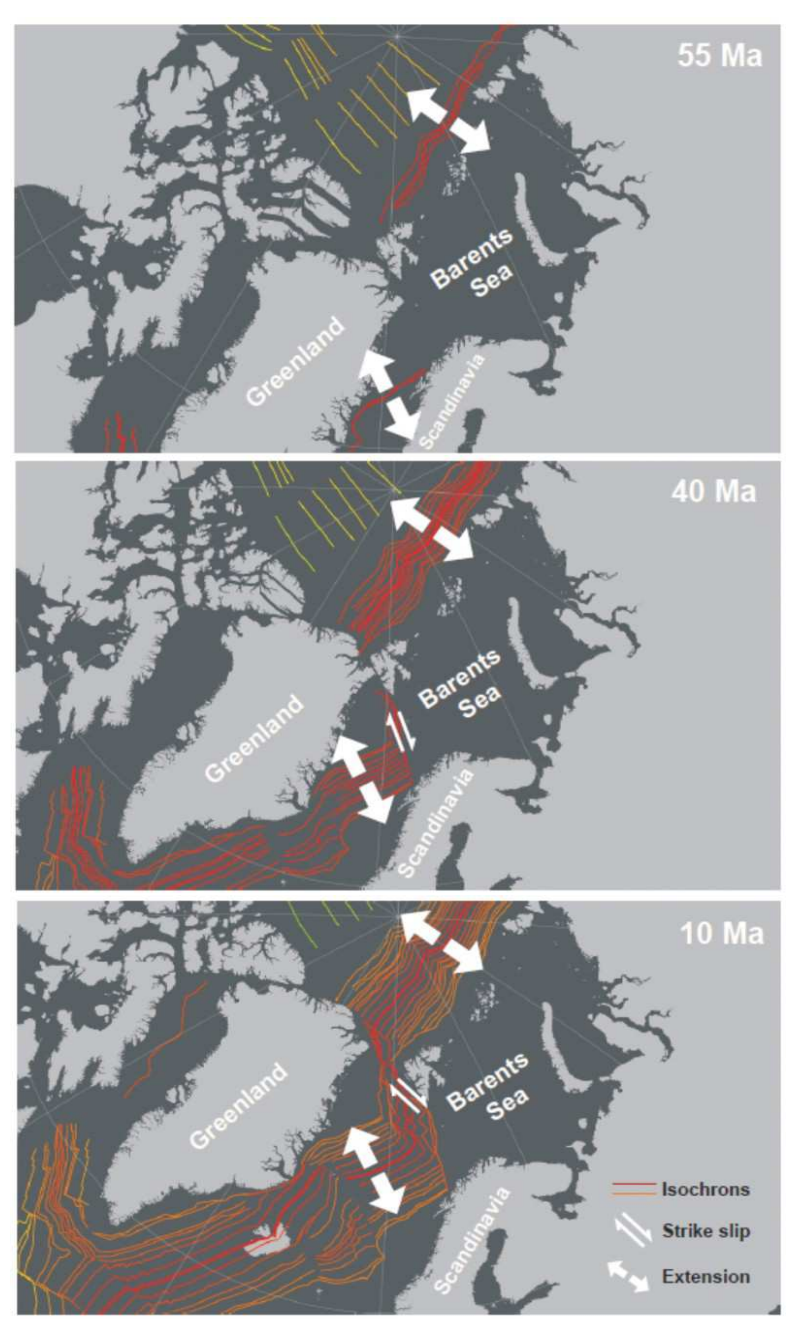

Fig. 2. Plate tectonic reconstruction of the Barents Sea region for $55 \mathrm{Ma}, 40 \mathrm{Ma}$ and $10 \mathrm{Ma}$ for the reconstruction we used the GPlates software and data-sets provided by (Seton et al., 2012)

Shortly after, major episodes of sea-floor spreading affected the Barents Sea (Faleide et al., 2008) and probably caused uplift in the regions close to the main tectonic activity (Fig. 2). In Eocene to Miocene times, the uplifted parts of the Barents Sea shelf were subject to erosion and the eroded material was deposited in the southern and eastern Barents Sea (Rasmussen and Fjeldskaar, 1996; Dimakis et al., 1998). In the HB two major cooling phases linked to uplift and erosion, dated between $\sim 40$ and $20 \mathrm{Ma}$ and $\sim 20$ and $0 \mathrm{Ma}$, were identified using AFTA (Green and Duddy, 2010). The younger event coincides with latest sediment logical and geochemical evidence from the Atlantic-Arctic gateway, which indicates that the entire northwestern European margin was elevated above sea level and eroded during the late Miocene-early Pliocene (Knies et al., 2014).
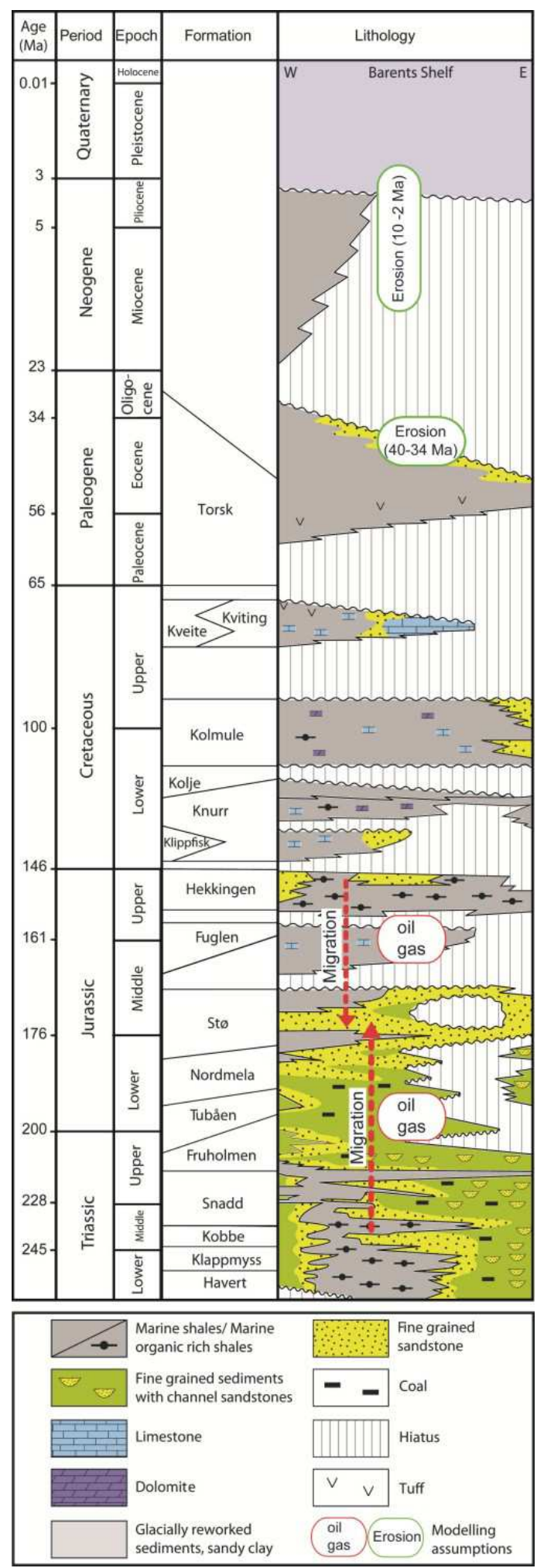

Fig. 3. Simplified lithostratigraphic column of the Barents Sea (from Ostanin et al. 2012, based on references given therein) with a schematic overview of the source rockcarrier bed system setup used in the petroleum migration/accumulation modeling 


\section{Method}

The modeling of gas and oil migration in the HB was conducted by using the basin modeling tool SEMI (Sylta, 2004). SEMI was developed to quantify hydrocarbon migration and exploration risk. It includes also functions for simulating the generation and expulsion of hydrocarbons from source rocks. The software uses a ray-tracing technique to migrate fluids from a source rock through a carrier bed into a reservoir. SEMI allows also modeling of hydrocarbon leakage out of the traps. The technique is map-based and pathway directions are mainly determined by the dip of the carrier unit and migration barriers (Sylta, 2004).

The entire basin model of the western part of the HB was set up. The following elements of the basin model were considered: (a) Present day maps of geological layers including properties and type of rocks, (b) deposition ages and stratigraphy of each layer and timing of erosion events, (c) paleo-geometries including water depth maps for each layer and erosion maps, d) temperature boundary conditions (sediment-waterinterface temperatures, paleo-thermal model).

The basin modeling involved thickness and paleogeometry restoration of sedimentary layers by applying the backstripping technique (e.g., Watts and Ryan, 1976). We employed the sedimentary rock porosity-depth relations of Sclater and Christie (1980). The next steps included the simulation of source rock maturation, petroleum expulsion out of the source rock and secondary hydrocarbon migration (Sylta, 2004). Our base model was calibrated against published VR data (NPD data) for maximum paleo-thermal conditions and against BHT and DST thermal data for the present day thermal setting.

The input overpressure maps were simulated using the Pressim software tool which models pressure generation and dissipation over geological time scale (Borge, 2000; Lothe, 2004). The basic assumption behind this technique is that the fluid flow dynamics can be represented and described by pressure compartments defined by faults (Borge and Sylta, 1998). All geological layers are classified as either reservoir or sealing units. A Kozeny-Carman equation is used to relate permeability from the shale porosities. The porosities are provided by the empirical shale compaction models.

Several processes were modelled; compaction, chemical effects like quartz cementation in the reservoir units (Walderhaug, 1996), pressure build up, hydraulic fracturing and leakage (Lothe, 2004). Overpressure maps were used as input into the migration modeling for all the sedimentary layers. SEMI computes the summed total pressures from the water phase (using the overpressure input maps from Pressim) and from the hydrocarbon columns. If the sum of these pressures is larger than the leak-off pressure (set at 0.9 of the overburden), the hydrocarbon columns are reduced until the total pressure no longer exceeds the leak-off pressures. The cap rock reseals itself so that the pressures do not decrease below the leak-off pressures.

All basin modeling steps were subjected to 3000 simulation runs, each using a new and different set of values for selected input parameters (Monte Carlo type simulations; Fig. 4). These parameters were described by deterministic values and an add-on value drawn from probabilistic distributions, characterized by a mean value and a standard deviation.

For each simulation run input values for selected parameters were drawn randomly from their assigned probabilistic distributions. The distribution types were set up based on available geological knowledge. A Gaussian distribution was used if a reasonable (most likely) mean could be estimated, otherwise a uniform distribution was considered. Values for the distribution's standard deviations were chosen in such a way that they account for uncertainties related to different parameter estimations (e.g., published erosion amounts) and different methodologies used for parameter determinations.

\subsection{Evaluation of the Monte Carlo Runs}

The best fitting results from the Monte Carlo simulation runs were used to determine the most probable value for input parameters initially considered as probabilistic distributions (Fig. 4). This is achieved by selecting those simulation runs which yielded the lowest misfits between modelled and measured hydrocarbon column heights. Measured oil and gas accumulations heights for several wells in the Stø Formation are reported by Norwegian Petroleum Directorate (www.npd.no) and from Statoil ASA (Table 1). Our misfit criterion considers both oil and gas column height fits Equation 1:

$$
\text { Misfit }=\left[\sum_{i=1}^{N}\left(h_{o n}^{o b s}\right)^{L}\right]^{\frac{1}{L}}+\left[\sum_{i=1}^{N}\left(h_{g n}^{\mathrm{mod}}-h_{g n}^{o b s}\right)^{L}\right]^{\frac{1}{L}}
$$

Where:

$h_{o n}^{\text {mod }}=$ Modelled oil column height for well number $\mathrm{n}$

$h_{o n}^{o b s} \quad=$ Observed oil column height for well number $\mathrm{n}$

$h_{g n}^{\text {mod }}=$ Modelled gas column height for well number $\mathrm{n}$

$h_{g n}^{o b s}=$ Observed gas column height for well number $\mathrm{n}$

$\mathrm{L} \quad=$ Scaling parameter

$\mathrm{N} \quad=$ Number of wells

For every suite of simulations, an individual number of best-fit runs was determined. A threshold is placed at the best $10 \%$ or less of the misfit values, determined in a suite of simulations. Therefore, as a $10 \%$ misfit value cut off is used, the actual number of best runs is variable between sets of simulations. 


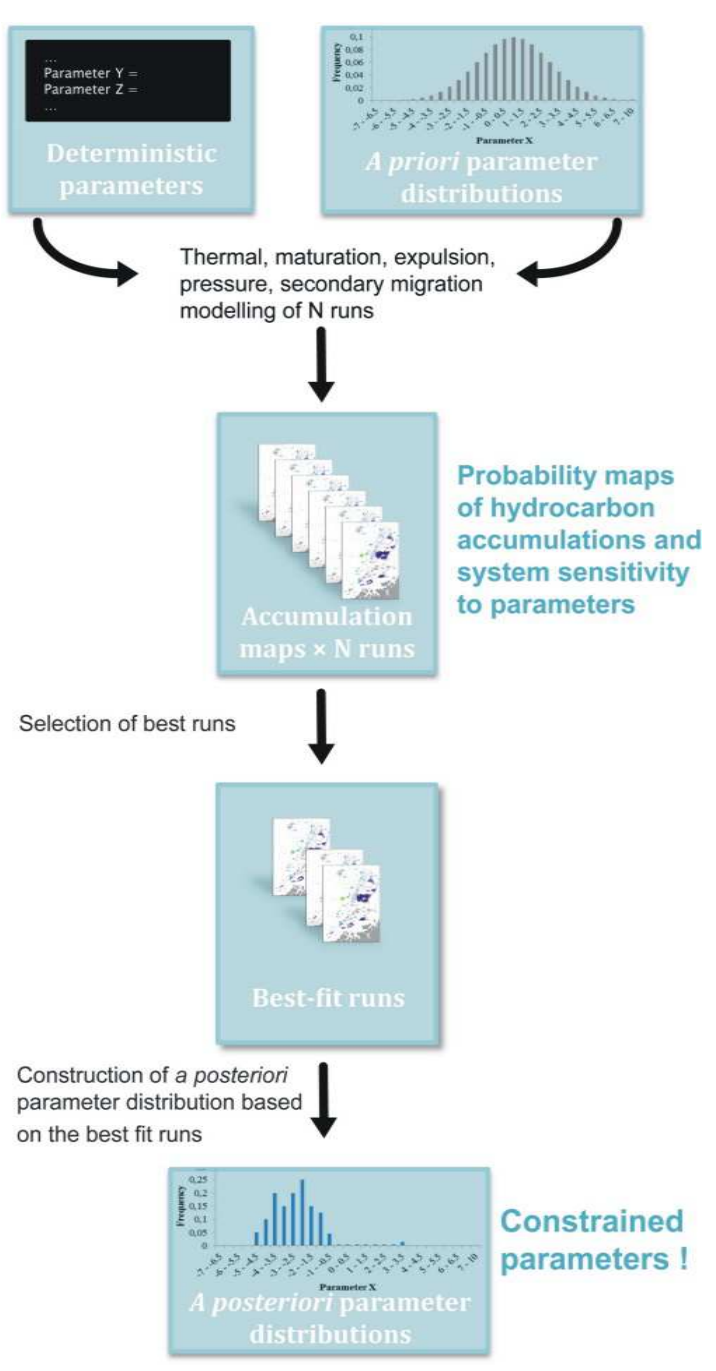

Fig. 4. Workflow for the Monte Carlo-secondary migration approach. This method is employed for constraining distributions of input parameters

Table 1. The Hammerfest Basin wells used for calibration of the modeled hydrocarbon column heights. Stø Fm. refers to Stø Formation - the main reservoir rock unit in the modelled petroleum system

\begin{tabular}{llll}
\hline well & longitude & latitude & Stø Fm. content \\
\hline $7120 / 6-1$ & 497650.92 & 7946756.85 & oil \& gas \\
$7120 / 7-1$ & 7912388.54 & 471011.63 & gas \\
$7120 / 7-2$ & 7913417.99 & 476011.92 & gas \\
$7120 / 8-1$ & 7923384.58 & 479897.51 & gas \\
$7120 / 8-2$ & 7915359.17 & 480927.89 & gas \\
$7120 / 9-1$ & 498124.67 & 7932342.99 & gas \\
$7121 / 4-1$ & 505507.86 & 7944529.35 & gas \\
$7121 / 4-2$ & 7950918.8 & 502204.76 & gas \\
$7121 / 5-1$ & 514306.93 & 7944421.61 & oil \& gas \\
$7121 / 5-2$ & 7952737.91 & 523051.48 & oil \& gas \\
$7121 / 7-1$ & 503105.18 & 7930306.01 & gas \\
$7121 / 7-2$ & 7927117.4 & 501987.36 & gas \\
$7120 / 6-2$ S & 493948.96 & 7944559.34 & oil \& gas \\
$7121 / 4-F-2 ~ H$ & 501998.86 & 7945754.16 & oil \& gas \\
$7121 / 7-N-3$ H & 502986.46 & 7932077.79 & oil \& gas \\
\hline
\end{tabular}

The best-fit runs were used to create a posteriori input distributions. Differences between the a priori (model setup) and a posteriori distributions may be interpreted as gain of knowledge about these parameters for the given model and geological setting (Fig. 4).

\subsection{Model Setup and Input Data}

For the basin model we used interpreted seismic horizon maps provided by Statoil ASA and two constructed horizons (Intra Sotbakken 10 and $34 \mathrm{Ma}$ ) (Table 2) as input to the geo-model. The additional horizons enabled the modeling of erosion at the given time steps. Lithological properties of the layers were set up by using available core description data from Norwegian Petroleum Directorate (www.npd.no). SEMI allows for a definition dual-lithology setup, where sedimentary rocks are considered as a proportional mixture of two rock types (Table 2).

This paper is focused on the Middle Jurassic petroleum play in which the Stø Formation is a carrier unit and charged with hydrocarbons from the source rocks of the Kobbe and Hekkingen formations (Fig. 3). For the migration modeling it was assumed that only a certain fraction of the expelled hydrocarbons will migrate to the carrier unit.

\subsection{Probabilistic Parameters}

Three key model parameters were defined in probabilistic form: (a) Early Cenozoic (40-34 Ma) erosion amount, (b) late Cenozoic (10-2 Ma) erosion amount and (c) temperature gradient. Each of these parameters is composed of the deterministic component value (e.g., a map of the magnitude of erosion) and the probabilistic add-on modifiers. Values of the add-on modifiers are changed for every simulation run, since they represent a draw from assigned probability distributions (see section 3.1). For both, the early and late Cenozoic erosion amounts, the deterministic components were derived from cooling amount assessed by AFTA and VR well data (Duddy, 1998). A conversion into erosion amounts was done by assuming specific geo-thermal gradients during Cenozoic times. A detailed description of the method is given in (Green and Duddy, 2010) and case studies presented in (Japsen et al., 2010). The paleothermal gradient maps were constructed by using a combination of maximum paleo-thermal gradients, estimated from VRdepth profiles and present day geothermal gradient from BHT, DST data. These data were gridded up as maps.

In this study, erosion estimates based on input from wells 7120/8-1, 7120/9-2 and 7121/4-1 were employed (Fig. 5). Based on these erosion estimates, maps were created by using standard interpolation methods in Petrel software. We decided to use half of the inferred erosion amounts as the deterministic component of the probabilistic erosion parameter as a base case. 
Table 2. Stratigraphic input to the basin model outlining the two dominant lithologies and boundary ages for each stratigraphic unit. For description see text

\begin{tabular}{|c|c|c|c|c|c|c|}
\hline Base horizon & Top horizon & $\begin{array}{l}\text { Age of } \\
\text { base }[\mathrm{Ma}]\end{array}$ & $\begin{array}{l}\text { Age of } \\
\text { top [Ma] }\end{array}$ & $\begin{array}{l}\text { Lithology } \\
\text { type } 1\end{array}$ & $\begin{array}{l}\text { Lithology } \\
\text { type } 2\end{array}$ & $\begin{array}{l}\text { Rate between lith. } \\
1 \text { and lith. } 2\end{array}$ \\
\hline Base Quaternary & Seabed & 2 & 0 & Shale & Sand & 0.4 \\
\hline Intra Sotbakken & Base Quaternary & 10 & 2 & Shale & Sand & 0.3 \\
\hline Intra Sotbakken & Intra Sotbakken & 34 & 10 & Shale & Sand & 0.3 \\
\hline Top Torsk & Intra Sotbakken & 40 & 34 & Shale & Sand & 0.3 \\
\hline Base Cenozoic & Top Torsk & 66 & 40 & Shale & Sand & 0.4 \\
\hline Top Kolje & Base Cenozoic & 125 & 66 & Shale & Limestone & 0.2 \\
\hline Top Hekkingen & Top Kolje & 145 & 125 & Shale & Limestone & 0.2 \\
\hline Top Fuglen & Top Hekkingen & 156 & 145 & Shale & Sand & 0.1 \\
\hline Top Stø & Top Fuglen & 168 & 156 & Shale & Limestone & 0.1 \\
\hline Top Nordmela & Top Stø & 183 & 168 & Shale & Sand & 0.9 \\
\hline Top Tubåen & Top Nordmela & 197 & 183 & Shale & Sand & 0.8 \\
\hline Top Fruholmen & Top Tubåen & 204 & 197 & Shale & Sand & 0.8 \\
\hline Top Kobbe & Top Fruholmen & 237 & 204 & Shale & Sand & 0.7 \\
\hline Top Permian & Top Kobbe & 251 & 237 & Shale & Sand & 0.5 \\
\hline
\end{tabular}
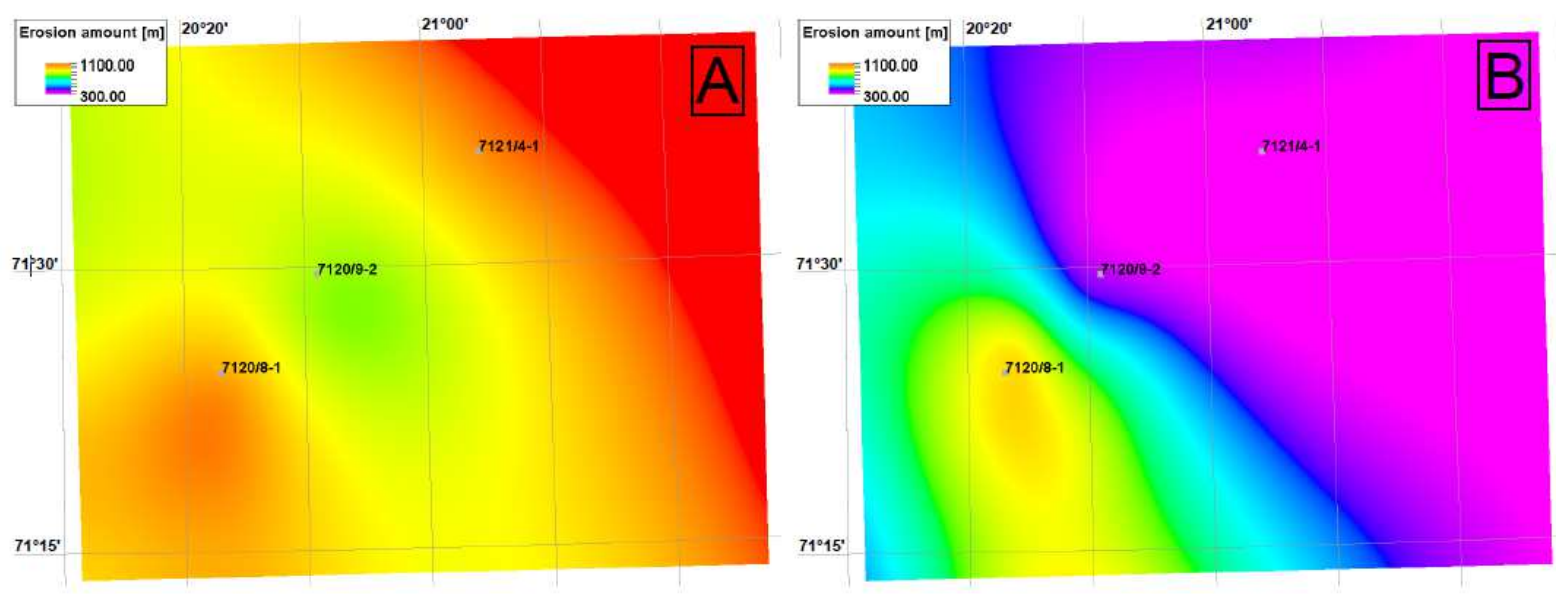

Fig. 5. Early and late Cretaceous base case maps. They are the results of AFTA and VR erosion estimates interpolation. The map values were reduced by $50 \%$ in order to add add-on variables which were defined as statistical distributions

We believe, based on the literature and data set review (Bjørlykke et al., 1989; Linjordet and Grung-Olsen, 1992; Riis and Fjeldskaar, 1992; Tsikalas, 1992; Walderhaug, 1992; Richardsen et al., 1993; Ohm et al., 2008), that this base case is a conservative minimum erosion amount estimate for each event in the region. These base case erosion maps yield amounts of 8201100 and $250-985 \mathrm{~m}$ for the early and late Cenozoic events, respectively (Fig. 5). We assumed Gaussian distributions for the add-on modifier of the erosion parameters with a mean value and a standard deviation (1 sigma) of $500 \mathrm{~m}$ for the early Cenozoic event and 250 $\mathrm{m}$ for the late Cenozoic event. Both distributions were truncated at zero to avoid negative erosion estimates.

For the temperature gradient input parameter a set of gradient maps were constructed as the deterministic component. They are based on present day thermal gradients measured in deep wells. The add-on modifiers are drawn from a Gaussian distribution with mean value of $1^{\circ} \mathrm{C} / \mathrm{km}$ and with standard deviation of $2{ }^{\circ} \mathrm{C} / \mathrm{km}$ (1 sigma).

\subsection{Modeling Scenarios}

Two scenarios were subjected to Monte Carlo simulation runs. In scenario $\mathrm{A}$, we tested a base case assuming only sedimentary loading as an overpressure generating mechanism (no input overpressure maps used) and capillary leakage from traps was enabled. In scenario B, a pre-calculated overpressure history (see section 3, Appendix 1) of the carrier was incorporated in the model. Overpressure maps were calculated by using Pressim software. Also, hydraulic leakage was enabled as a second trapping failure mechanism. This can be interpreted as an end-member model. Overpressure build up in the carrier is governed by compartments bounded by low permeable faults. It can result in fracturing of the cap rock above traps and trap depletion enclosed in the modelled pressure compartments. The overpressure can 
also change the migration paths and possible spill to oil and gas accumulations (Lothe et al., 2006). The input maps used from the overpressure modeling are shown in Appendix 1. Except for the overpressure and leakage mechanisms the remaining basin model setup is identical for both models (see section 3.2).

\section{Results}

\subsection{All Modeling Runs}

As a result of the 6000 simulation runs for both scenarios, a set of 3000 different input variable combinations were obtained. In general, scenario A simulations show marginally higher misfit values (from 27 to $64 \mathrm{~m}$ ) then scenario B runs (from 27 to $59 \mathrm{~m}$ ) (Equation 1). For both scenarios the early Cenozoic erosion amount modifiers vary between 0 and $2225 \mathrm{~m}$ with the mean value of $644 \pm 394 \mathrm{~m}$. The late Cenozoic modifiers range from 0 to $1124 \mathrm{~m}$ with mean value of $320 \pm 198 \mathrm{~m}$. Temperature gradient modifier values range from -5.5 to $8.7^{\circ} \mathrm{C} / \mathrm{km}$ with the mean value of $1.1 \pm 2^{\circ} \mathrm{C} / \mathrm{km}$ (Table 3 ).

The hydrocarbon column height fit (defined by misfit parameter) was analyzed against variable input parameters (Fig. 6). The figure shows misfit-input parameters relationships in scenario $\mathrm{B}$, but the trends and values for the scenario A are very alike as summarized in Table 3. It was found that the misfit is not sensitive to temperature gradient modifier (Fig. 6c), but is slightly dependent on the late Cenozoic erosion amount modifier (Fig. 6b) and dependent on the early Cenozoic erosion amount modifier (Fig. 6a). The misfit of the latter parameter is the lowest for the lowest early Cenozoic erosion amount. The parameter shows low misfit for the values below $514 \mathrm{~m}$ (in scenario B) and $429 \mathrm{~m}$ in scenario A. Above this value misfit increases significantly up to value of $1658 \mathrm{~m}$ and for the higher values it decreases again. A certain late Cenozoic erosion amount value may show huge scatter of the misfit values. The minimum possible misfit value may be however achieved if the parameter is around $150 \mathrm{~m}$.

\subsection{Best-Fit Runs}

For both scenarios the 250 best-fit simulation runs were selected which is $8.3 \%$ of all modeling runs. This number relates to rapid increase of the misfit value against the early Cenozoic erosion amount modifier (see section 4.1 and Fig. 6a). The input variables of these 250 runs were analyzed and used to derive a posteriori parameter distributions (see section 3).

\subsection{Erosion Scenarios}

In scenario A the early Cenozoic erosion amount modifiers range from $1 \mathrm{~m}$ to $429 \mathrm{~m}$. The mean value is $206 \pm 148 \mathrm{~m}$. By adding this mean value to the deterministic base-case erosion map (Fig. 5), the erosion amounts vary between 1026 and $1306 \mathrm{~m},( \pm 148 \mathrm{~m})$.

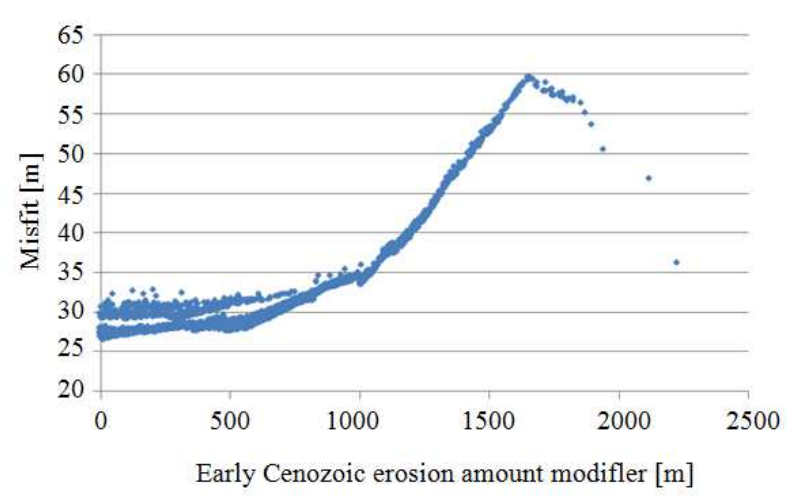

(A)

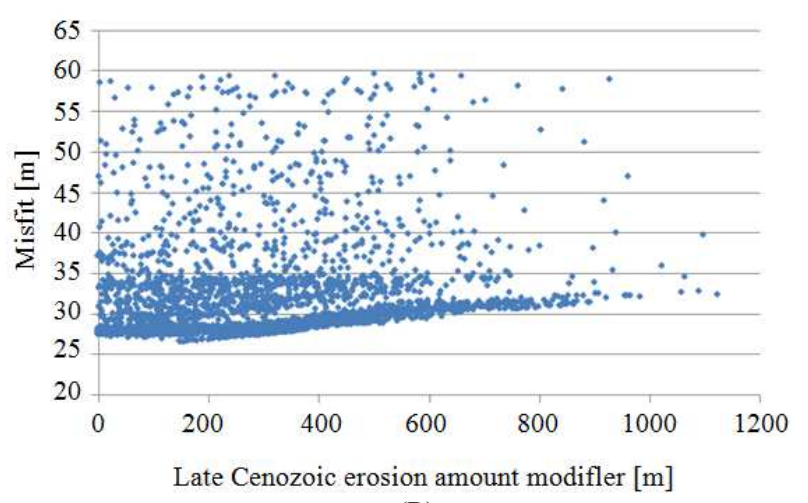

(B)

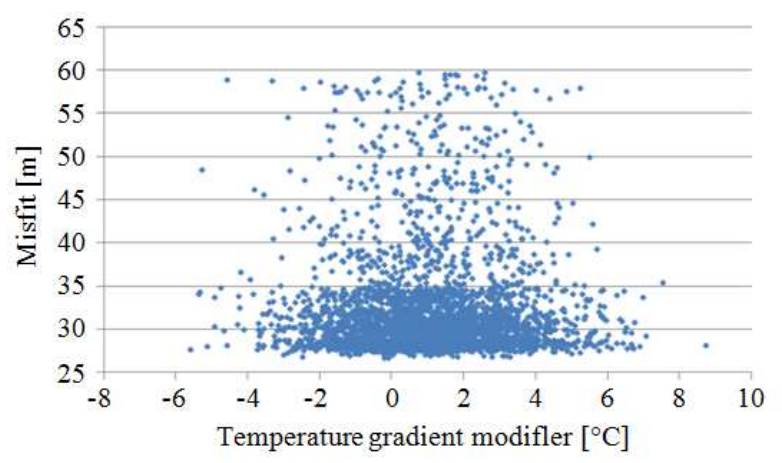

(C)

Fig. 6. Model input variables versus misfit for all 3000 runs for scenario B (including overpressure modeling). (A) Early Cenozoic erosion amount modifier, (B) late Cenozoic erosion amount modifier, (C) temperature gradient modifier

In scenario $\mathrm{B}$ the minimum and maximum values are quite similar to scenario A spanning a range from $0 \mathrm{~m}$ to $514 \mathrm{~m}$, but the mean value and standard deviation is lower $(142 \pm 122 \mathrm{~m})$. This yields final erosion amounts, achieved by adding this mean value to the deterministic base-case erosion map, of between 962 and $1242 \mathrm{~m}( \pm 122 \mathrm{~m})$ (Fig. 7a, b, Table 3). 
The late Cenozoic erosion amount modifier values of scenario A vary between $1 \mathrm{~m}$ and $359 \mathrm{~m}$ with mean value of $167 \pm 92 \mathrm{~m}$. The total erosion amounts (deterministic base-case map plus the modifier) range from 417 to $1152 \mathrm{~m}$
$( \pm 92 \mathrm{~m})$. In scenario $\mathrm{B}$ the values are very similar to scenario A, ranging from $1 \mathrm{~m}$ to $333 \mathrm{~m}$ with a mean value of $182 \pm 93 \mathrm{~m}$. The total erosion is calculated to range from 432 to $1167 \mathrm{~m}$ ( $\pm 93 \mathrm{~m})$, (Fig. 7c, d and Table 3).
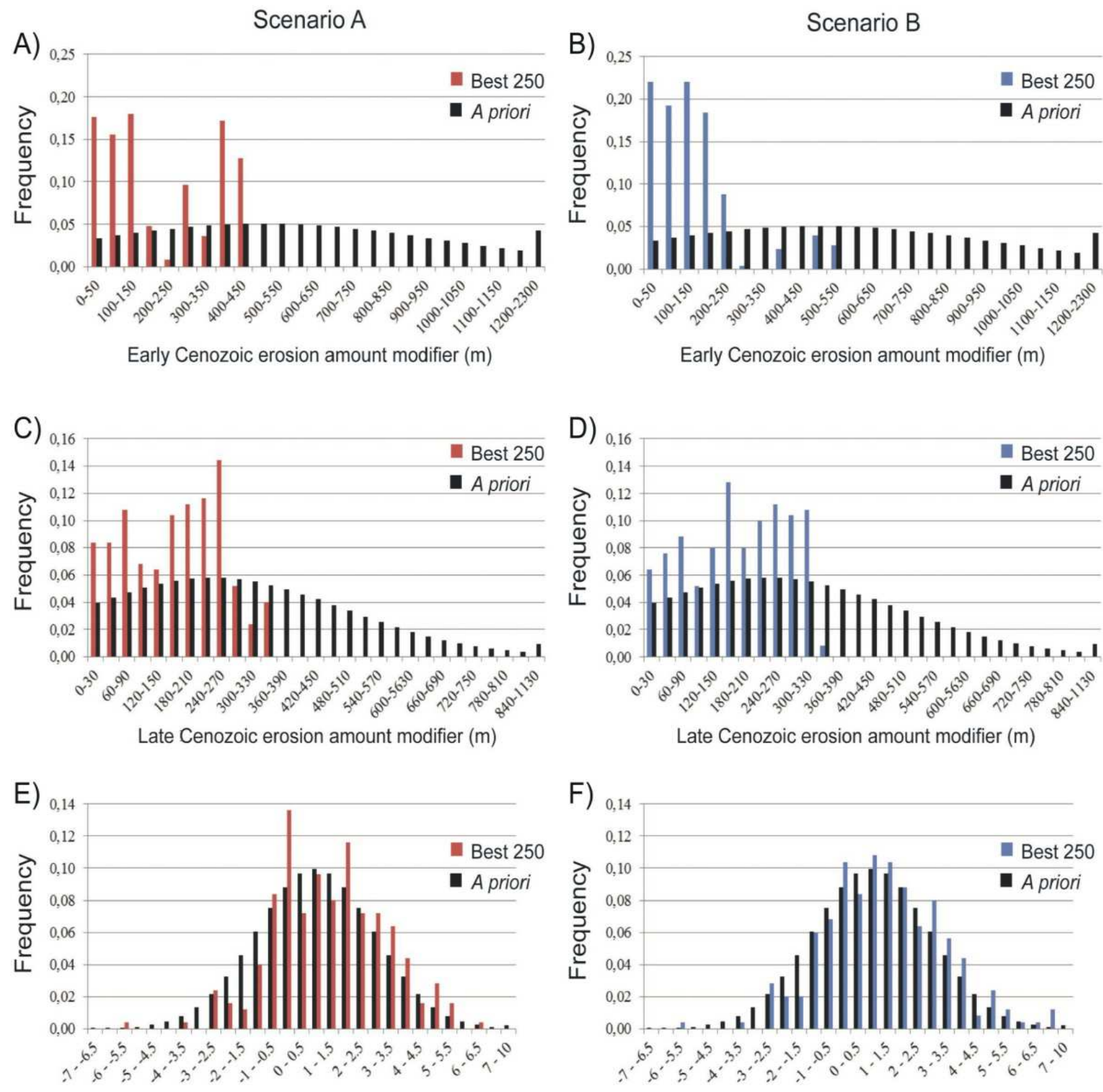

Thermal gradient modifier $\left({ }^{\circ} \mathrm{C} / \mathrm{km}\right)$

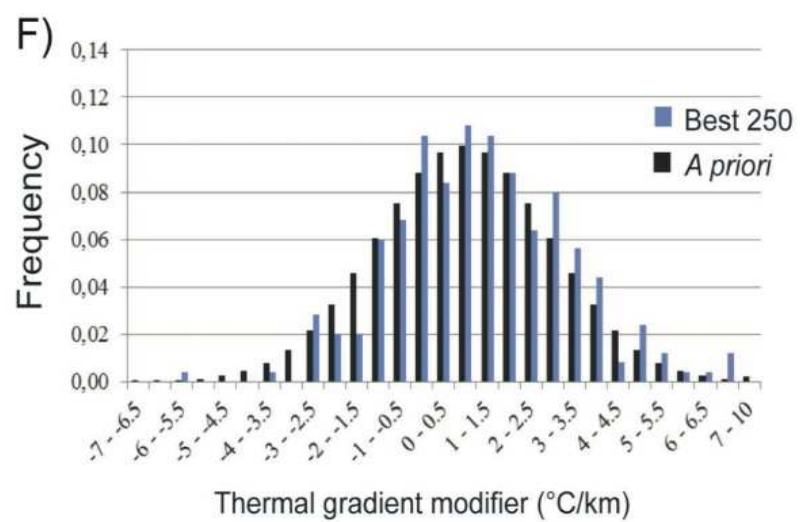

Fig. 7. Probabilistic results for estimates of erosion amount modifiers (A, B, C, D) and thermal gradients (E, F) for modelled scenario A and scenario B (see text for scenario definition). Histograms display both a priori (black bars) and a posteriori (red and blue bars) probability distributions of the add-on modifiers. The mean early Cenozoic amount of erosion modifier distribution is $500 \mathrm{~m}$ with a standard deviation of $500 \mathrm{~m}(\mathrm{~A}, \mathrm{~B})$. The mean late Cenozoic amount of erosion modifier distribution is $250 \mathrm{~m}$ with a standard deviation of $250 \mathrm{~m}(\mathrm{C}, \mathrm{D})$. All distributions are normal and truncated at 0 . The thermal-gradient model was composed of base-case maps (defined for each time step) and probabilistic add-on modifiers. A priori distributions are normal with a mean value of $1^{\circ} \mathrm{C}$ and a standard deviation of $2^{\circ} \mathrm{C}$ 
Table 3. Outline of statistical parameters for the investigated input of the study results. The table shows a shift in parameter distributions between a priori and best 250 simulation runs (a posteriori) distributions. A priori refers to all 3000 simulation runs performed for two pressure-compaction scenarios. Scenarios A and $\mathrm{B}$ refer to different pressure-compaction scenarios. The scenarios are described in the text

\begin{tabular}{llccc}
\multicolumn{4}{c}{ scenarios. The scenarios are described in the text } \\
\hline & & $\begin{array}{l}\text { Early } \\
\text { Cenozoic } \\
\text { ero. am. } \\
\text { mod. }[\mathrm{m}]\end{array}$ & $\begin{array}{l}\text { Late } \\
\text { Cenozoic } \\
\text { ero. am. } \\
\text { mod. }[\mathrm{m}]\end{array}$ & $\begin{array}{l}\text { Temp. } \\
\text { gradient } \\
\text { modifier } \\
{\left[{ }^{\circ} \mathrm{C} / \mathrm{km}\right]}\end{array}$ \\
\hline A priori: & min & 0 & 0 & -5.5 \\
All runs & max & 2225 & 1124 & 8.8 \\
& std. & 394 & 198 & 2.0 \\
Scenario A: & min & 644 & 320 & 1.1 \\
The best & max & 429 & 359 & -5.5 \\
250 runs & std. & 148 & 92 & 6.1 \\
& mean & 206 & 167 & 1.9 \\
Scenario B: & min & 0 & 1 & -5.5 \\
The best & max & 514 & 333 & 6.8 \\
250 runs & std. & 122 & 93 & 2.0 \\
& mean & 142 & 182 & 1.1 \\
\hline
\end{tabular}

Comparing the results of scenario A (without overpressure) and scenario B (with overpressure history included), we see that the overpressure has a larger influence on the Early Cenozoic erosion amount (Fig. 7a and b) than on the late Cenozoic one (Fig 7c and d). In scenario $\mathrm{A}$, the best 250 runs show the erosion amount modifier value between 0 and $450 \mathrm{~m}$. However, including the overpressure maps through time (Scenario B) most of the best 250 runs have the early Cenozoic erosion amount modifier value between 0 and $250 \mathrm{~m}$ (Fig. 7b). For the late Cenozoic erosion amount (Fig. 7c and $\mathrm{d}$ ), the difference between the 250 best runs (both without and with overpressure history included) is not so large, but slightly higher number of modeling runs which values are higher than $300 \mathrm{~m}$ was found.

The total amount of the Cenozoic erosion, which is considered to be a sum of the base-case maps and mean erosion amount values ranges from 1526 to $2411 \mathrm{~m}$ for scenario A and from 1477 to $2362 \mathrm{~m}$ for scenario B in the study area.

\subsection{Net Erosion}

Net erosion is defined as a difference between maximum burial depth and present depth for a marker horizon. Therefore it differs from the total erosion amount which does not consider the amount of deposition (England and Molnar, 1990). In fact our erosion amount estimates refer to the total erosion amount which is either equal or higher that the net erosion. Except for (Duddy, 1998; Green and Duddy, 2010; Duran et al., 2013) the erosion amount estimates published since the 1980 's refer to net erosion amount (Fig. 8b). In order to check how the modeling results fit the literature, calculations of the net erosion were performed by using standard decompaction procedure in the SEMI software.

In both scenarios the maximum burial depth was reached at $40 \mathrm{Ma}$ in the almost entire area. In the neighborhood of the well 7120/8-1 the maximum burial depth was reached a $10 \mathrm{Ma}$. The resulting net erosion varies between 400 and $784 \mathrm{~m}$ in scenario $\mathrm{A}$ and between 348 and $733 \mathrm{~m}$ in scenario B.

\subsection{Thermal Gradient}

For the thermal gradient modifier distributions no significant discrepancy was found between a priori and a posteriori distributions. In both scenarios a posteriori mean values are about $1{ }^{\circ} \mathrm{C} / \mathrm{km}$ which is approximately equal to the a priori distribution mean value. Similar values were also found in standard deviation which is about $2^{\circ} \mathrm{C} / \mathrm{km}$ in both a priori and a posteriori distributions (Fig. 7e and f). The best value for the geothermal gradient according to the Monte Carlo simulations is $36.1 \pm 2^{\circ} \mathrm{C} / \mathrm{km}$.

\section{Discussion}

Our erosion amount estimates distinguish between early and late Cenozoic amounts and the results indicate that overall the early Cenozoic erosion event was dominant with mean erosion amounts of about 1.0-1.3 km depending on basin location and pressureleakage scenario. Similar amounts are reached locally by the late Cenozoic erosion, but in general the late Cenozoic erosion was lower $(0.4-1.2 \mathrm{~km})$. The late Cenozoic erosion is concentrated in southwestern part of the study area due to base case map deviation (Fig. 5 ). The early Cenozoic erosion is much less localized than the late Cenozoic event showing relatively low erosion amount deviation.

Our early Cenozoic erosion estimates are much lower than the erosion estimate in well 7120/9-2 (Green and Duddy, 2010) but coincide with range of the late Cenozoic erosion amounts reported in the entire HB by Duran et al. (2013) (Fig. 8a). The calculated Cenozoic total erosion varies between 1.5 and $2.4 \mathrm{~km}$ across the area which is lower than the estimates made by Green and Duddy (2010) $(2.8 \mathrm{~km})$ and higher than those made by Duran et al. (2013) (0.3-1.5 km). Duran et al. (2013) estimates represent a similar petroleum system modeling approach to the one presented here. In their study, three different erosion scenarios (varied spatially) were tested and calibrated against the present day temperature and VR measurements. The best fit was achieved by using the highest possible erosion amount scenario (Fig. 8a) supporting the view that petroleum system modeling of the HB produces matching results if a substantial erosion amount is assigned. 


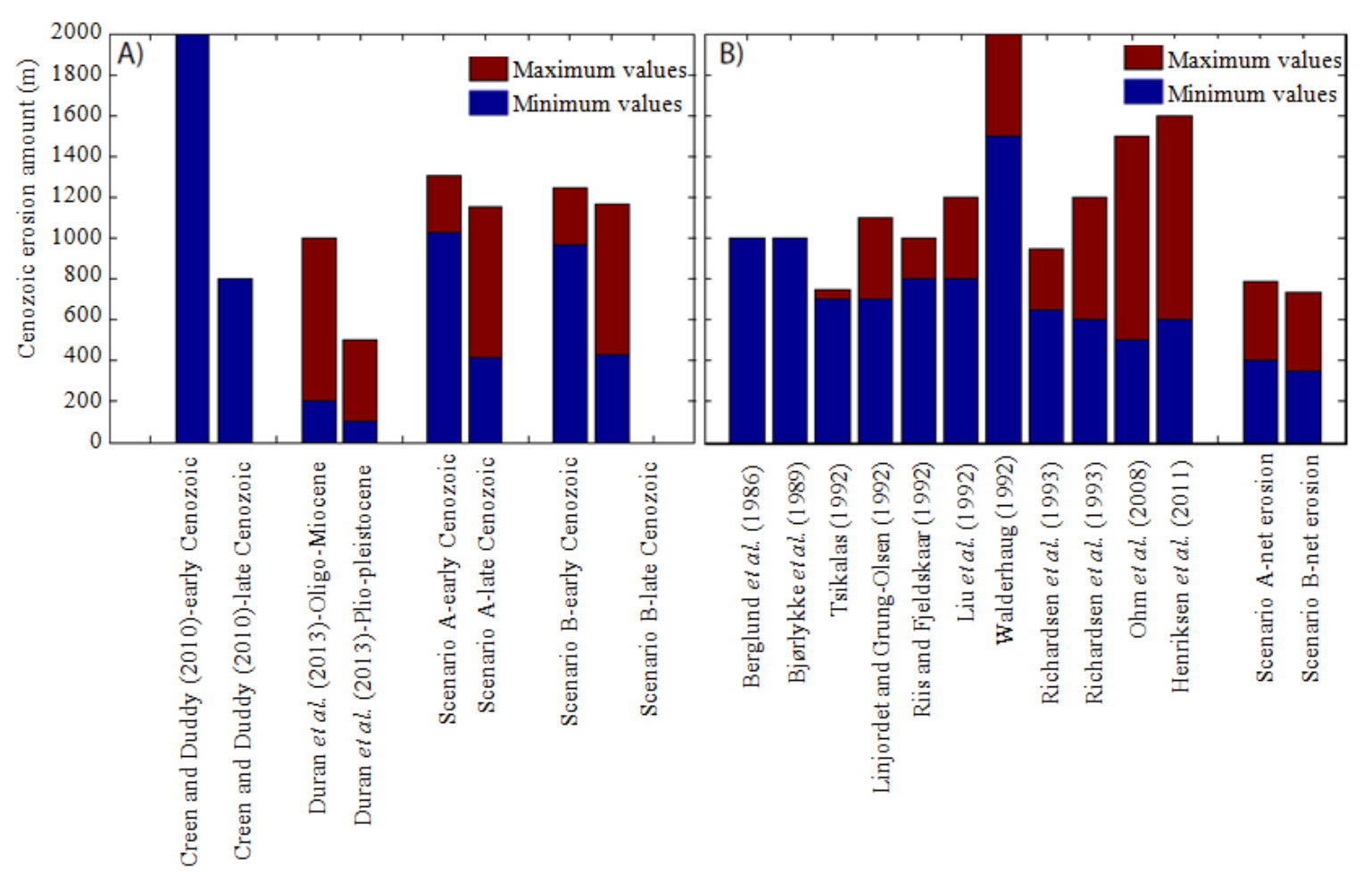

Fig. 8. Compilation of erosion estimates for Cenozoic times from previous publications and the results reported in here. (A) Total erosion amount (B) net erosion amount

We have showed that the net erosion ranges between 0.3-0.8 km. These values correspond with those in the literature but represent rather lower boundary estimates (Fig. 8b). Given that the study area is localized in the western part of the HB, we attribute this difference to a decreasing trend of net erosion amount towards the western margin of the Barents Sea as described by Henriksen et al. (2011a).

Literature does not put focus on the effect of water fluid overpressures on hydrocarbon migration modeling combined with erosion and uplift. Cavanagh et al. (2006) modelled the reservoir pressure (Stø Formation) in the Snøhvit area in the range of 5-10 MPa, depending on the glacial cycles' character and erosion amount. Their overpressure modeling was carried out for the last $1 \mathrm{Ma}$ similarly to Duran et al. (2013) who conducted overpressure modeling for the last 1.2 Ma. In this study, we have modelled hydrocarbon migration including various erosion amounts and different overpressure scenarios for the last $40 \mathrm{Ma}$. The high overpressure modelled in the Eocene has impact on erosion amount that gives the best fit (Fig. 7a, b and Appendix 1). Moreover the study shows that for the early Cenozoic erosion phase, a low misfit is calculated with erosion map varying from 700 to $1100 \mathrm{~m}$ laterally (Fig. 5a) and with a modifier from 0 to about $500 \mathrm{~m}$ (Fig. 6a). Higher erosion amounts result in significant misfit increase (Fig. 6a). The same trend cannot however be observed for the late Cenozoic erosion event (Fig. 6b). This result indicates that the effect of the early Cenozoic erosion phase should not be underestimated. Furthermore, the results suggest that tectonic events during the Late Cenozoic might not have had an effect on the migration history as significant as the early Cenozoic uplift event.

Several theories have been proposed about the cause of erosion in the study area. Henriksen et al. (2011a) provide a literature review of the erosion amount estimates and driving forces of the Cenozoic uplift. They suggest the following possible uplift and erosion mechanisms: (a) Opening of the Atlantic and Arctic Oceans, (b) compression and/or transpression, (c) isostatic response to sediment unloading and (d) postglacial rebound. Dating results (Duddy, 1998) mainly support the first two mechanisms. We believe that the two erosion events between 40 and $34 \mathrm{Ma}$ and between 10 and $2 \mathrm{Ma}$ coincide with major plate tectonic reorganizations in sea-floor spreading in the NorwegianGreenland Sea and the associated development of a trans-tensional regime along the De Geer Zone megashear system (Faleide et al., 2008) following the western Barents Sea to Svalbard axis (Fig. 2). The ages of the late Eocene erosion event coincide with timing of the rift flank uplift in the Barents Sea (Dimakis et al., 1998) and an increased amount of erosion affecting the southwestern Barents Sea. The late Cenozoic erosion age $(10-2 \mathrm{Ma})$ is supported by sedimentological and 
geochemical data from the Atlantic-Arctic gateway showing that the entire northwestern European margin was uplifted during the late Miocene-early Pliocene (Knies et al., 2014).

In the Barents Sea the uplifted terrain is believed to be further affected by several glaciations leading to the shelf erosion in a range of $0.8-1.0 \mathrm{~km}$ (Laberg et al., 2012). Glaciations in the southern Barents Sea are thought to commence about 1.0 Ma (Knies et al., 2009) which does not coincide with the ages of erosion detected by AFTA used in this study (Duddy, 1998). According to AFTA dating the most recent Barents Sea cooling episode occurred before glacial events (10-5 $\mathrm{Ma})$. This cooling is thought to be driven by a regional tectonic cause resulting in regional uplift and erosion (Duddy, 1998; Green and Duddy, 2010). As mentioned, we relate this cause to plate tectonic reorganization and seafloor spreading. Moreover, we speculate that another reason why the glaciation events were not detected is the low net erosion amount; below the sensitivity of the AFTA method. This might occur if the glacial erosion coexisted with substantial amount of glacial deposition. However, an estimation of the glacial deposition amounts on the Norwegian shelf has not yet been published and in order to investigate this hypothesis this topic should be studied in detail.

\section{Conclusions}

Here we presented a novel stochastic basin modelling approach to quantify erosion and associated uncertainties in the western Hammerfest Basin. The modelling results indicate:

- The early Cenozoic erosion amount oscillated between 1.0 and $1.3 \mathrm{~km}$

- The late Cenozoic erosion amount ranges from 0.4 to $1.2 \mathrm{~km}$

- $\quad$ Estimated net erosion varied from 0.3 to $0.8 \mathrm{~km}$

- Overpressure scenarios had a limited effect on modelled erosion amounts

- The early Cenozoic uplift and erosion had a significantly higher impact on the hydrocarbon migration compared to the late Cenozoic event

\section{Acknowledgement}

We acknowledge Statoil ASA for providing data. We appreciated the profound comments of two anonymous reviewers.

\section{Funding Information}

This work is a contribution to Strategic Institute Program (SIP 186919) "Top seal integrity and leakage, with relevance for exploration risk in the Barents Sea" (2008-2010) funded by Research Council of Norway.

\section{Author's Contributions}

This paper presents the main results from a MSc thesis of KJZ who analyzed, interpreted the results and coordinated the study. The thesis was supervised by SL and MD. MD set up and performed the basin modelling and contributed to sections 3,4 and 5. BE contributed to all the sections and organized the paper's framework. AL and AG contributed to section 3, 4 and 5 .

\section{Ethics}

This article is original and contains unpublished material. The corresponding author confirms that all of the other authors have read and approved the manuscript and no ethical issues involved.

\section{References}

Berglund, L.T., J. Augustson, R.B. Færseth, J. Gjelberg and H. Ramberg-Moe, 1986. The evolution of the Hammerfest Basin. In: Habitat of Hydrocarbons on the Norwegian Continental Shelf, Spencer, A.M. (Ed.), Graham and Trotman for the Norwegian Petrolium Society, London, ISBN-10: 0860108333, pp: 319-338.

Bjørlykke, K., M. Ramm and G.C. Saigal, 1989. Sandstone diagenesis and porosity modification during basin evolution. Geologische Rundschau, 78: 243-268. DOI: 10.1007/BF01988363

Borge, H., 2000. Fault controlled pressure modeling in sedimentary basins. Norwegian University of Science and Technology.

Borge, H. and Ø. Sylta, 1998. 3D modelling of fault bounded pressure compartments in the North Viking Graben. Energy Exploration Exploitat., 16: 301-323.

Cavanagh, A.J., R. Di Primio, M. Scheck-Wenderoth and B. Horsfield, 2006. Severity and timing of Cenozoic exhumation in the southwestern Barents Sea. J. Geological Society, 163: 761-774. DOI: $10.1144 / 0016-76492005-146$

Clark, S.A., E. Glorstad-Clark, J.I. Faleide, D. Schmid and E.H. Hartz et al., 2013. Southwest Barents Sea rift basin evolution: Comparing results from backstripping and time-forward modelling. Basin Res., 26: 550-566. DOI: 10.1111/bre.12039

Dalland, A., D. Worsley and K. Ofstad, 1988. A Lithostratigraphic Scheme for the Mesozoic and Cenozoic and Succession Offshore Mid- and Northern Norway. 1st Edn., Oljedirektoratet, pp: 130.

Dimakis, P., B.I. Braathen, J.I. Faleide, A. Elverhøi and S.T. Gudlaugsson, 1998. Cenozoic erosion and the preglacial uplift of the Svalbard-Barents Sea region. Tectonophysics, 300: 311-327. DOI: 10.1016/S0040-1951(98)00245-5

Duddy, I.R., 1998. The Barents Sea-thermal, tectonic and hydrocarbon maturation histories assessed using apatite fission track analysis and vitrinite reflectance. Geotrack International Pty Ltd. 
Duran, E.R., R. di Primio, Z. Anka, D. Stoddart and B. Horsfield, 2013. 3D-basin modelling of the Hammerfest Basin (South Western Barents Sea): A quantitative assessment of petroleum generation, migration and leakage. Marine Petroleum Geol., 45: 281-303. DOI: 10.1016/j.marpetgeo.2013.04.023

England, P. and P. Molnar, 1990. Surface uplift, uplift of rocks and exhumation of rocks. Geology, 18: 1173-1177. DOI: 10.1130/0091-7613(1990) $018<1173$ :SUUORA $>2.3$. CO; 2

Faleide, J.I., F. Tsikalas, A.J. Breivik, R. Mjelde and O. Ritzmann et al., 2008. Structure and evolution of the continental margin off Norway and Barents Sea. Episodes, 31: 82-91.

Faleide, J.I., E. Vagnes and S.T. Gudlaugsson, 1993. Late Mesozoic-Cenozoic evolution of the South Western Barents Sea in a regional rift-shear tectonic setting. Marine Petroleum Geol., 10: 186-214. DOI: 10.1016/0264-8172(93)90104-Z

Gabrielsen, R.H., R.B. Færseth, L.N. Jensen, J.E. Kalheim and F. Riis, 1990. Structural elements of the continental shelf. Part I: The Barents Sea Region. Norwegian Petroleum Directoriate.

Gernigon, L., M. Bronner, D. Roberts, O. Olesen and A. Nasuti et al., 2014. Crustal and basin evolution of the southwestern Barents Sea: From Caledonian orogeny to continental breakup. Tectonics, 33: 347-373. DOI: 10.1002/2013tc003439

Glørstad-Clark, E., J.I. Faleide, B.A. Lundschien and J.P. Nystuen, 2010. Triassic seismic sequence stratigraphy and paleogeography of the western Barents Sea area. Marine Petroleum Geol., 27: 1448-1475. DOI: 10.1016/j.marpetgeo.2010.02.008

Green, P.F. and I.R. Duddy, 2010. Synchronous exhumation events around the Arctic including examples from Barents Sea and Alaska North Slope. Petroleum Geol. Conf. Series, 7: 633-644. DOI: $10.1144 / 0070633$

Henriksen, E., H.M. Bjornseth, T.K. Hals, T. Heide and T. Kiryukhina et al., 2011a. Chapter 17 Uplift and erosion of the greater Barents Sea: Impact on prospectivity and petroleum systems. Geological Society, London, Memoirs, 35: 271-281. DOI: 10.1144/M35.17

Henriksen, E., A.E. Ryseth, G.B. Larssen, T. Heide and K. Ronning et al., 2011b. Chapter 10 Tectonostratigraphy of the greater Barents Sea: Implications for petroleum systems. Geological Society, London, Memoirs, 35: 163-195. DOI: 10.1144/M35.10

Jakobsson, M., R. Macnab, L. Mayer, R. Anderson and M. Edwards et al., 2008. An improved bathymetric portrayal of the Arctic Ocean: Implications for ocean modeling and geological, geophysical and oceanographic analyses. Geophysical Res. Lett., 35: L07602- L07602. DOI: 10.1029/2008GL033520
Japsen, P., P.F. Green, J.M. Bonow, E.S. Rasmussen and J.A. Chalmers et al., 2010. Episodic uplift and exhumation along North Atlantic passive margins: Implications for hydrocarbon prospectivity. Petroleum Geol. Conf. Series, 7: 979-1004. DOI: $10.1144 / 0070979$

Knies, J., J. Matthiessen, C. Vogt, J.S. Laberg and B.O. Hjelstuen et al., 2009. The Plio-Pleistocene glaciation of the Barents Sea-Svalbard region: A new model based on revised chronostratigraphy. Quaternary Sci. Rev., 28: 812-829.

DOI: 10.1016/j.quascirev.2008.12.002

Knies, J., R. Mattingsdal, K. Fabian, K. Grøsfjeld and S. Baranwal et al., 2014. Effect of early Pliocene uplift on late Pliocene cooling in the Arctic-Atlantic gateway. Earth Planetary Sci. Lett., 387: 132-144. DOI: 10.1016/j.epsl.2013.11.007

Laberg, J.S., K. Andreassen and T.O. Vorren, 2012. Late Cenozoic erosion of the high-latitude southwestern Barents Sea shelf revisited. Geological Society Am. Bull., 124: 77-88. DOI: 10.1130/B30340.1

Linjordet, A. and R. Grung-Olsen, 1992. The Jurassic Snøhvit Gas Field Hammerfest Basin, Offshore Northern Norway. In: Giant Oil and Gas Fields of the Decade, 1978-1988, Halbouty, M.T. (Ed.), American Association of Petroleum Geologists, Tulsa, Okla, ISBN-10: 0891813330, pp: 526.

Liu, G.J., S. Lippard, S. Fanavoll, O. Sylta and S. Vassmyr et al., 1992. Quantitative geodynamic modelling of Barents Sea Cenozoic uplift and erosion. Norsk Geologisk Tidsskrift, 72: 313-316.

Lothe, A., 2004. Simulations of hydraulic fracturing and leakage in sedimentary basins. University of Bergen.

Lothe, A., Ø. Sylta, O. Lauvrak and S. Sperrevik, 2006. Influence of fault map resolution on pore pressure distribution and secondary hydrocarbon migration; Tune area, North Sea. Geofluids, 6: 122-136. DOI: $10.1111 /$ j.1468-8123.2006.00136.x

Ohm, S.E., D.A. Karlsen and T.J.F. Austin, 2008. Geochemically driven exploration models in uplifted areas: Examples from the Norwegian Barents Sea. AAPG Bulletin, 92: 1191-1223. DOI: $10.1306 / 06180808028$

Ostanin, I., Z. Anka, R. di Primio and A. Bernal, 2012. Identification of a large Upper Cretaceous polygonal fault network in the Hammerfest basin: Implications on the reactivation of regional faulting and gas leakage dynamics, SW Barents Sea. Marine Geol., 332-334: 109-125. DOI: $10.1016 /$ j.margeo.2012.03.005

Rasmussen, E. and W. Fjeldskaar, 1996. Quantification of the Pliocene-Pleistocene erosion of the Barents sea from present-day bathymetry. Global Planetary Change, 12: 119-133.

DOI: $10.1016 / 0921-8181(95) 00015-1$ 
Richardsen, G., T.O. Vorren and B.O. Torudbakken, 1993. Post-early cretaceous uplift and erosion in the southern Barents Sea A discussion based on analysis of seismic interval velocities. Norsk Geologisk Tidsskrift, 73: 3-20.

Riis, F. and W. Fjeldskaar, 1992. On the magnitude of the Late Tertiary and Quaternary Erosion and its Significance for the Uplift of Scandinavia and the Barents Sea. In: Structural and Tectonic Modeling and its Application to Petroleum Geology, Larsen, R.M., H. Brekke, B.T. Larsen and E. Talleraas (Eds.), NPF Special Publication, pp: 163-185.

Sclater, G.J. and P.A.F. Christie, 1980. Continental stretching: An explanation of the post-midcretaceous subsidence of the Central North Sea Basin. J. Geophysical Res., 85: 3711-3739. DOI: 10.1029/JB085iB07p03711

Seton, M., R.D. Müller, S. Zahirovic, C. Gaina and T. Torsvik et al., 2012. Global continental and ocean basin reconstructions since $200 \mathrm{Ma}$. Earth-Sci. Rev., 113: 212-270. DOI: 10.1016/j.earscirev.2012.03.002

Sylta, O., 2004. A probabilistic approach to improved geological knowledge and reduced exploration risks using hydrocarbon migration modelling. Petroleum Geosci., 10: 187-198.

DOI: $10.1144 / 1354-079303-607$
Sylta, O. and W. Krokstad, 2003. Estimation of oil and gas column heights in prospects using probabilistic basin modelling methods. Petroleum Geosci., 9: 243-254. DOI: 10.1144/1354-079302-563

Tsikalas, F., 1992. A study of seismic velocity, density and porosity in Barents Sea wells, Northern Norway. MSc Thesis, University of Oslo, Oslo, Norway.

Vorren, T.O., G. Richardsen and S.M. Knutsen, 1991. Cenozoic erosion and sedimentationn in the western Barents Sea. Marine Petroleum Geol., 8: 317-340. DOI: 10.1016/0264-8172(91)90086-G

Walderhaug, O., 1992. Magnitude of uplift of the Stø and Nordmela Formations in the Hammerfest Basin-a diagenetic approach. Norsk Geologisk Tidskrift, 72: 321-323.

Walderhaug, O., 1996. Kinetic modeling of quartz cementation and porosity loss in deeply buried sandstone reservoirs. AAPG Bull., 80: 731-745. DOI: 10.1306/64ED88A4-1724-11D78645000102C1865D

Watts, A.B. and W.B.F. Ryan, 1976. Flexure of the lithosphere and continental margin basins. Tectonophysics, 36: 25-44.

Worsley, D., 2008. The post-Caledonian development of Svalbard and the Western Barents Sea. Polar Res., 27: 298-317. DOI: 10.1111/j.1751-8369.2008.00085.x 


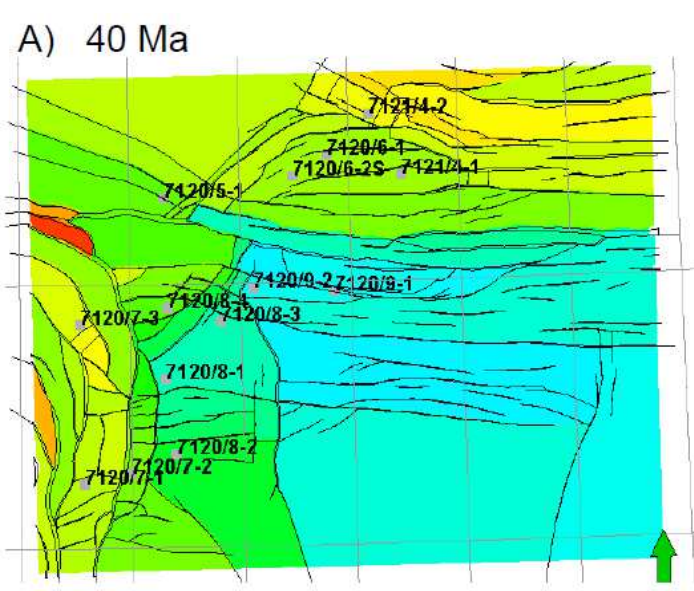

C) $10 \mathrm{Ma}$

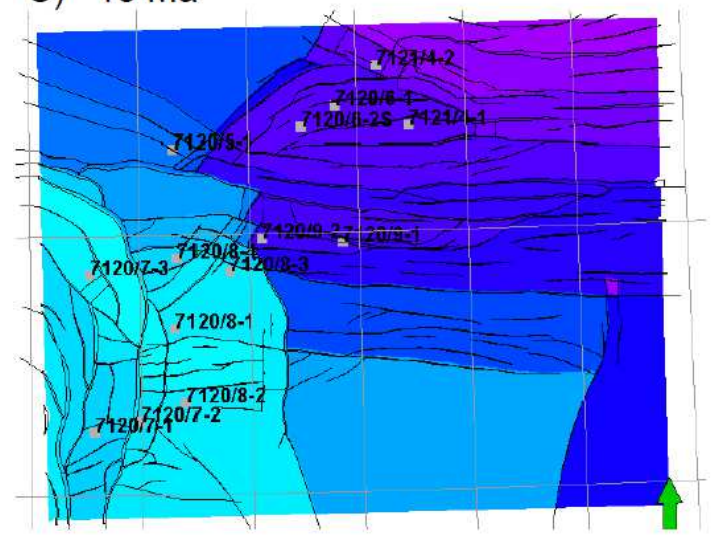

\section{E) $0 \mathrm{Ma}$}

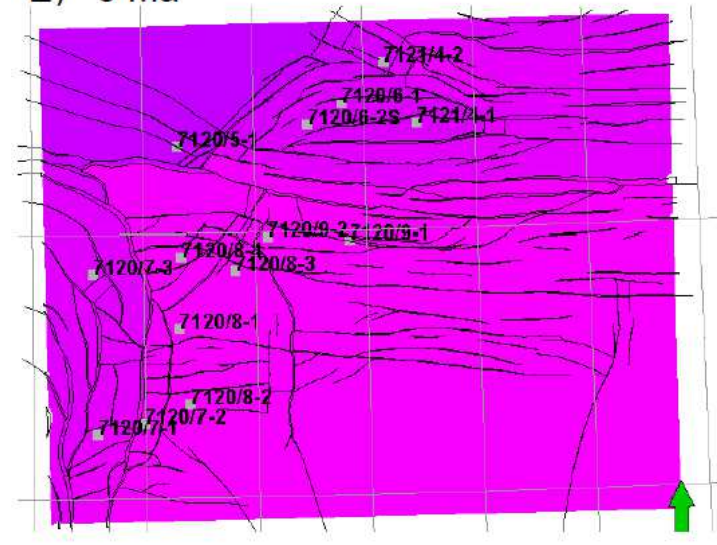

\section{B) $34 \mathrm{Ma}$}

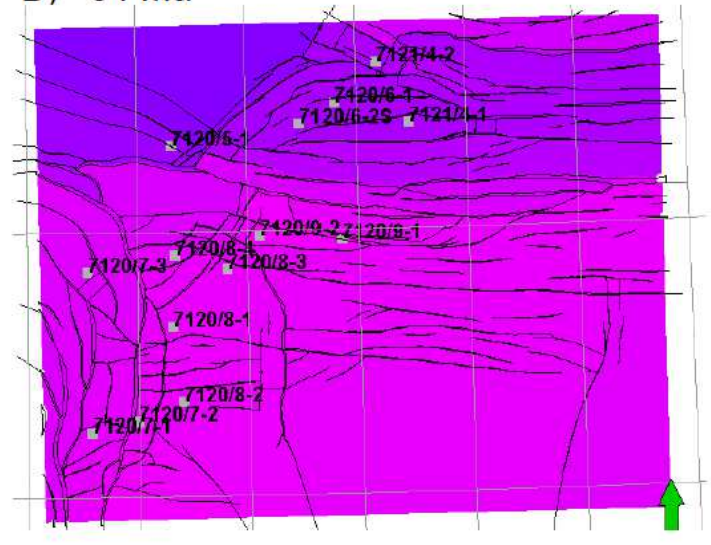

D) $2 \mathrm{Ma}$

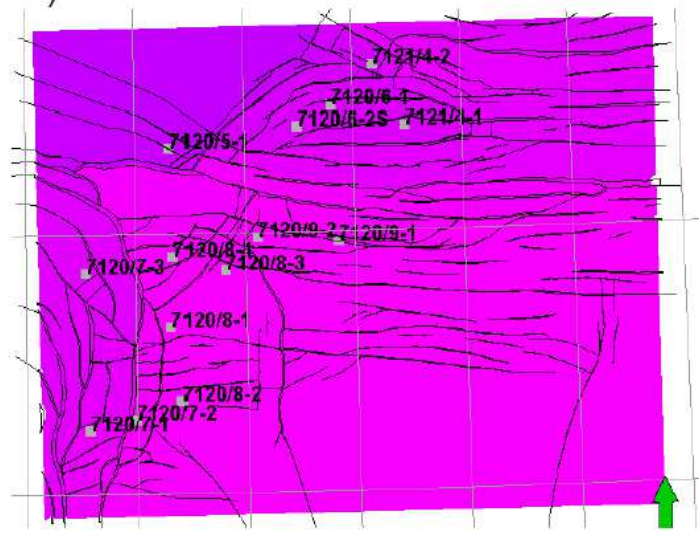

\section{Overpressure [bar]}

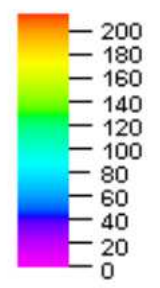

Appendix 1. Overpressure maps used as input for the basin model. These were used only in modeling scenario B (for details see section 3.4). No overpressure for the time steps before $40 \mathrm{Ma}$ was detected 